\title{
Counting by "elevens" and why nine and two make twenty: The material roots of Polynesian numbers
}

\author{
Karenleigh A. Overmann \\ University of Bergen, Norway \\ University of Colorado, Colorado Springs, USA \\ karenleigh.overmann@keble.oxon.org
}

\begin{abstract}
Traditional Polynesian number systems provide interesting and occasionally surprising insights into the elaboration of numerical structure and organization. While strongly decimal and capable of counting into the millions, these number systems also developed divergent ways of counting specific types of objects, and objects could be counted collectively (by twos, fours, or eights) as well as singly (one by one). Toward the eastern periphery of the region, in Mangareva, three unique binary steps were also incorporated into an otherwise decimal structure. Here these elaborations are shown to have a material basis: they are the logical outcomes of pragmatic counting methods that minimized physical and mental effort. The elaboration of numbers through the counting methods used highlights the centrality of material forms to the structure and organization of both numerical concepts and their verbal labels. These insights position our manuovisual engagement of material forms alongside language as an interdependent, coinfluential, and ultimately distinct means of accessing and elaborating human numerical intuitions, one whose investigation has the potential to yield new insights into human numeracy.
\end{abstract}

Keywords: Numerical Cognition, Binary Numeration, Cognitive Tools, Cultural Representations, Mental Arithmetic, Material Engagement Theory

\section{Introduction}

The traditional number systems of Polynesia, while strongly decimal, were elaborated in complex and interesting ways. A general counting sequence coexisted with different ways of counting specific types of objects. The specified counting systems differed, from both the general system and each other, in the number-words used; by whether objects were counted one by one, or by twos, fours, or eights; and the inclusion (or not) of "scores." A few number-words were used in more than one counting sequence, sometimes keeping the same numerical value and other times assuming new ones, making numerical value dependent on the context of use. And in Mangareva, which lies along Polynesia's eastern periphery, a counting sequence included three unique binary steps (Bender \& Beller, 2014, 2017). 
Historically, the study of traditional Polynesian number systems has been approached through their number-words. This is not unusual, as it rests on the idea that language is essential to numbers, which is not new. It is found, for example, in the work of philosopher John Locke, whose 1690 essay on "human understanding" stated that number-words were "necessary" for numbers, as they were what enabled people to count and manipulate numbers, as well as conceive new ones (Locke, 1690, Book 2, Chapter XIV, Sect. 6). More recent linguists have reiterated the necessity claim: "Without language, no numeracy" (Hurford, 1987, p. 305). A related idea, that numbers are essentially linguistic in nature, has been promoted by linguist Noam Chomsky. He sees numbers as a subset of language, an "“abstraction"” that preserves the ability to produce a potentially infinite number of meaningful expressions ("discrete infinity") while eliminating other features of language (Chomsky, 1988, p. 169).

Reinforcing the necessity and essentiality claims is the circumstance that, in the absence of notations, number-words are overt and unambiguous evidence of numbers. However, notations and language are not the only forms numbers can take. Material forms other than notations are used to represent and manipulate numbers: the fingers; devices that accumulate, like tallies; and devices that accumulate and group, like the abacus. While the ubiquity of such devices has long been acknowledged (e.g., Ifrah, 1981; Menninger, 1992), their influence on the conceptualization of numbers has been poorly understood, until recently. New analyses suggest that such devices precede and inform the development of notations; occasion the naming of numbers in language; give numbers their properties of linearity, manipulability, dimensionality, and concision; and act as the mechanism of numerical elaboration (Overmann, 2016a, 2016b, $2018,2019)$. These contributions position material devices and their manuovisual engagement as a means of accessing numerical intuitions that is distinct from language, a means that 
acknowledges quantity as a perceptual primitive (Dehaene, 2011; Piazza, 2011) and material rearrangement and display as implicit to mathematical visualization (Dreyfus, 1991; Kaput, 1987) and epistemology (Giaquinto, 2007; Nelsen, 1993).

Traditional Polynesian number systems provide an ideal case study for testing the hypothesis that numbers have a material basis, as they have hitherto been studied through language, appear to have lacked notations prior to European contact, ${ }^{1}$ and have been perceived as using few material devices to represent and manipulate numbers. The theoretical framework, data, and method of analysis used in the study were as follows:

Theoretical framework. The theoretical framework used, Material Engagement Theory, assumes that cognition is extended and enacted (Malafouris, 2013). Extended means that material devices are a constitutive part of cognition, while enacted means that cognition is the interaction between brain, body, and world (Clark \& Chalmers, 1998; Hutto, 2013). Simply, the boundaries of cognition are drawn differently: cognition includes the body and world, rather than being isolated in the brain. On this view, materiality is not a passive, external support to cognitive processes; it is instead a constitutive component of the cognitive system for numbers (Overmann, 2016a, 2019). The important question is not whether this theoretical construct models cognition "more correctly" than the traditional, Cartesian model, but rather, whether it is capable of generating novel insights.

Data. Traditional Polynesian number systems were surveyed in terms of number-words, ${ }^{2}$ numerical structure, organization, and extent. Both contemporary and historical sources were

\footnotetext{
${ }^{1}$ A possible exception is the Rongorongo script of the island of Rapa Nui, discovered in the $19^{\text {th }}$ century. It remains mostly undeciphered but possibly functioned as a mnemonic device for chants (Davletshin, 2012; Fischer, 1997). Whether its invention predated European contact has not been established either, and the idea of writing is known to have been introduced in Rapa Nui in the late $18^{\text {th }}$ century, specifically in the form of numerals (González de Haedo, 1770).

2 Throughout the manuscript, Polynesian words are presented as given in the sources cited, rather than in standardized modern orthography, in order to emphasize their documentation in the period of contact and exploration that contributed to Western knowledge of Polynesian languages and number systems in the $18^{\text {th }}$ and $19^{\text {th }}$ centuries. Note that the historical literature often refers to "a" language of an island group, rather than specifying which island or dialect, and this can minimize significant local differences in number systems, such as those between the northern and southern Marquesas (e.g., Hale, 1846).
} 
consulted, with emphasis given to the latter, as contemporary accounts reflect number systems with centuries of Western influence, while historical observations recorded-albeit imperfectly — traditional practices as they existed when Western influence was minimal. These data were considered in light of the cultural context, wherein certain objects were counted often and to significant amounts (Bender \& Beller, 2007). Additionally considered were physical characteristics of enumerated objects (e.g., size and weight) and the physical and mental demands associated with counting heavy, bulky items in quantities of hundreds or thousands.

Method of analysis. To examine the possibility that traditional Polynesian number systems had a material basis capable of generating novel insights into numerical structure, organization, and vocabulary, Polynesian number-words and counting methods were plotted geographically and analyzed for what they could reveal about change associated with progressive settlement (published as Figure 4 in Overmann, 2020). In addition, the historical literature was culled for descriptions of counting practices. Next, an analysis was performed to assess constraints and tradeoffs in counting (e.g., Table 2) and formulate algorithms (Figures 3 and 4) that could illustrate counting methods consistent with observations of specified counting, collective counting, and binary steps. Finally, the algorithms were verified by comparing their output to historically documented numbers and counting methods (e.g., Best, 1906; Clark, 1839; Ellis, 1826; Hiroa, 1938; Janeau, 1908; Maunsell, 1842; Williams, 1844). The results of the analysis are provided below.

\section{Traditional Polynesian number systems and progressive settlement}

As Polynesia was progressively settled from west to east over the last 3000 years (Rieth \& Cochrane, 2018), the colonists took with them a decimal number system that appears based on 
using the fingers to count, as suggested by words like lima, which means both five and hand (Hale, 1846, p. 249; Williams, 1893, p. 24), and ngahuru, a word for ten that means all the fingers on both hands closed (Best, 1906, p. 157). As is typical in decimal systems, productive terms emerged at the multiples or exponents of 10, corresponding to the English words for decimal powers: hundred, thousand, ten thousand, hundred thousand, and million. This strongly decimal structure is interesting in and of itself, as Polynesians have been understood as using few material devices for counting and as not developing notations prior to European contact.

While the exponential structure was regularly and strongly decimal, the names of the higher values shifted around somewhat in the order of their sequence (see Table 1). For example, while afe meant 1000 and mano 10,000 (or uncountably large number) in the western part of Polynesia, afe disappeared and mano meant 1000 in eastern Polynesia (except in the Rapanui language), suggesting the sequence may have been imperfectly recalled as settlement expanded. The valuation of mano as 10,000 on Rapa Nui, given the island's wide separation from the western part of Polynesia, is more difficult to explain as an instance of misremembering, though the insertion of etymologically uncertain piere (Englert, 1977) into the sequence suggests the phenomenon, as does the use of tinitini at $10^{6}$ instead of the predicted $10^{4}$.

These changes in the names of higher exponents suggest that numbers were included in the phenomenon whereby the significant reduction in group size associated with remote colonization can cause complex skills to attrite or disappear, while simpler skills persist and intensify (Henrich, 2004). Every time a small group left its original society to colonize a remote island, counting to higher numbers likely occurred less frequently, since such counting took place in contexts like feasting and the surplus it represents, conditions less prevalent especially 
Table 1. Regular decimal powers; shifting names

\begin{tabular}{|c|c|c|c|c|c|c|c|}
\hline \multirow[b]{2}{*}{$\mathrm{Nr}$} & Tongic & \multicolumn{4}{|c|}{ Sāmoic-Outlier } & \multicolumn{2}{|c|}{ Marquesic } \\
\hline & Tongan & Sāmoan & Tuvaluan & Tikopian & Tokelauan & Marquesan & Hawaiian \\
\hline \multirow{6}{*}{$\begin{array}{l}10^{1} \\
10^{2} \\
10^{3} \\
10^{4} \\
10^{5} \\
10^{6} \\
10^{7}\end{array}$} & $\begin{array}{l}\text { hongofulu } \\
\text { teau }\end{array}$ & $\begin{array}{l}\text { sefulu, ngafulu } \\
\text { lau, selau }\end{array}$ & $\begin{array}{l}\text { sefulu } \\
\text { selau }\end{array}$ & $\begin{array}{l}\text { agafulu } \\
\text { rau }\end{array}$ & $\begin{array}{l}\text { fulu, ngafulu } \\
\text { lau, helau }\end{array}$ & $\begin{array}{l}\text { onohuu } \\
\text { tekau, au }\end{array}$ & $\begin{array}{l}\text { 'umi, kanaha } \\
\text { lau }\end{array}$ \\
\hline & & & & afe & & mano & mano \\
\hline & mano & mano & sefulu afe & (mano) & (mano) & tini & \\
\hline & kilu & & selau afe & & & tufá & lehu \\
\hline & & & & & & & nalowale \\
\hline & $\mathrm{Ma}$ & uesic & & & Tahitic & & \\
\hline $\mathrm{Nr}$ & Mangarevan & Rapanui & Tuamotuan & Tahitian & Rarotongan & Moriori* & Māori \\
\hline $10^{1}$ & takau & agahuru & horihori & ahuru & ngauru & ngauru & ngahuru \\
\hline $10^{2}$ & rau & rau & репи & rau & rau & rau & rau \\
\hline $10^{3}$ & mano & piere & mano & mano & mano & $?$ & mano \\
\hline $10^{4}$ & makiu & mano & & manotini & tini & tini & (tini) \\
\hline $10^{5}$ & makiukiu & lehu & & rehu & & pio & \\
\hline $10^{6}$ & makorekore & tinitini & & $i u$ & & rea & \\
\hline
\end{tabular}

Notes. Across Polynesian languages and the associated number systems, productive terms for the powers of 10 emerge regularly and predictably, and up to 100 their names are recognizably the same. From 1000 and up, highervalue names shift in the order of their sequence (e.g., mano is 10,000 in the western part of Polynesia and 1000 in central and eastern Polynesia except in the Rapanui language), and unique terms are also introduced (e.g., $i u$ for 1,000,000 in Tahitian; piere for 1000 in Rapanui). Tonga lies at the western extent of Polynesia and represents an older branch of the Polynesian language family (Charpentier \& François, 2015; Guérin, 2017), while the island of Rapa Nui lies at Polynesia's easternmost edge and represents a more recently diverged linguistic group (Lynch, Ross, \& Crowley, 2011; also see Figure 1). The geographic distribution implies the changes of names and values was an effect of regional migration, with change in the value of mano likely occurring early in the eastward expansion. While the value found in the Rapanui language at the Polynesia's eastern boundary is an exception, other changes suggest misremembering (e.g., the injection of piere for 1000). Key. Mano is highlighted in bold to aid comparison across languages. Parentheses enclose numerical terms that mean large (or uncountably large) number, rather than the exponent labeling the row. An asterisk $(*)$ means the language is extinct. Data sources: Tongan: Martin (1818); Rabone (1845); Sāmoan: Violette (1879); Tuvaluan: Besnier (1999); Tikopian: Durrad (1913); Tokelauan: Hale (1846); Simona (1986); Marquesan: Dordillon (1857); Hale (1846); Hawaiian: Clark (1839); Mangarevan: Hiroa (1938); Rapanui: Fuentes (1960); Roussel (1908); Tuamotuan: Audran (1920); Hale (1846); Tregear (1895); Tahitian: Davies (1851); Rarotongan: Buzacott (1854); Hale (1846); Moriori: Deighton (1889); Shand (1895); Māori: Best (1906); Williams (1844).

during the initial phase of settlement. In addition, fewer people knew the higher exponents in the first place, even in well-established colonies: as William Crook observed in 1797, "It is but a few of the Islanders who are capable of reckoning the highest Sums [i.e., exponents]; but some have ideas perfectly clear, of numbers still higher than those already given, reckoning ten tinnes to a Tuheva, and ten tuhevas to one pohho; which amounts to, from 4 to 5 Millions" (Crook, 2007, p. 73). This is analogous to contemporary unfamiliarity with terms like quadrillion (or billard, 
$10^{15}$ ), quintillion $\left(10^{18}\right.$ ), and sextillion (or trilliard, $10^{21}$ ). Further, some numerical terms were polyvalent, acquiring different exponential value according to their context of use. For example, au meant hundred in the general Tongan number system for counting most objects but took the value thousand in the specified systems for counting fish, yam, and coconuts (Beller \& Bender, 2005; Bender \& Beller, 2007). Cumulatively, these factors might have caused alteration in the order of the sequence of names for the higher exponents or occasioned substitutions within it. ${ }^{3}$

Another change likely attributable to a reduction to and intensification of core counting practices is the loss of the elaborate numeral classifiers prevalent in the western part of Polynesia but much less prevalent in peripheral regions (north, Hawai'i; east, Rapa Nui; south, New Zealand). Numeral classifiers helped differentiate the various specified number systems for counting different types of objects. In Sāmoa, for example, there were nearly a dozen derived systems and associated classifiers, depending on whether the objects being counted were young pigs and coconuts; coconuts by the score; fowls, breadfruit, and certain shellfish; crayfish; fish; bonito; taro; yams; bananas; fermented breadfruit; or dishes of food cooked in leaves (Pratt, 1862, pp. 8-9). Such linguistic encoding would have helped people remember the type of commodity being counted, in addition to the quantity itself, in the absence of notations for recording results. The decreased prevalence of numeral classifiers would be consistent with circumstances of counting in an initially more limited fashion in newly established colonies, in terms of both smaller

\footnotetext{
${ }^{3}$ Such change is unsurprising, for two reasons. First, human memory is never infallible, even in cultures using oral forms like chants to preserve their knowledge and history. While "an extreme concern for the accurate transmission" has been associated with the Māori oral tradition (McLean, 1961, p. 59), "fidelity of transmission has never been absolute," especially when the "web of oral transmission" has been attenuated, which may occur when a song is transmitted by only a few knowledgeable individuals who lack "community reinforcement and correction" (McLean, 1977, pp. 31-33). Such effects are plausibly construed to have occurred during Polynesia's progressive settlement. Second, chants were not static forms but allowed for improvisation, word substitution, and intentional "garble" intended to keep traditions like chants and dance from being overly exposed to non-initiates. The term kake, "chants with mixed or garbled words, for and by chiefs, with inserted syllables and some secret words," is relevant (Kaeppler, 1987; "kake," 2019). Further, Hawaiian language use-particularly in chants - prioritized performative displays of expressive word choice and naming, personality and personalization, detail, subtlety, humor, and wit (Kamali 'i, 1983), all of which admit possibilities for change in memorized sequences.
} 
numbers and fewer types of goods.

Other changes in numerical structure, organization, and language were influenced by the way counting was performed. Throughout the region, Polynesians counted objects "collectively" (Alexander, 1864, p. 13), not just one by one but in pairs, fours, and even eights. In Tonga, "in counting out yams and fish, they reckon by pairs" (Martin, 1818, p. 370), while in the Marquesas, breadfruit "were counted in bunches of fours called pona (literally, knot)" (Handy, 1923, p. 184). Counting things by eights was reported for Mangareva: "Le tauga est composé de huit objets réunis [The tauga is composed of eight objects combined]" (Janeau, 1908, p. 8). Counting by pairs was a practice with particular longevity in the region, suggested by Polynesian terms analogous to buku, "two [coco]nuts fastened together," and musuveisā, "to give in pairs," in Fijian (Hazlewood, 1850, pp. 19, 94), a language closely related to the Polynesian language family that is often used to anchor it in relational analyses (see Figure 1). Terms like buku, musuveisa $\bar{a}$, and pona suggest a reason collective counting might develop: as bundles made to facilitate carrying and other handling.

Pair-counting caused polyvalence and, in central and eastern Polynesia, an upward shift in numerical values by a factor of two, with mano having the value 2000 (Tonga) or 20,000 rather than 1000 or 10,000 , and number systems occasionally being mistaken for vigesimal rather than decimal (e.g., Best, 1907). These effects were found in Tonga, Rarotonga, Tahiti, Mangareva, and New Zealand (Bender \& Beller, 2007; Dordillon, 1857; Hale, 1846; Lee, 1820; Tregear, 1899; Williams, 1844). Similarly, counting by fours upwardly shifted numerical values by a factor of four in Hawai' $i$ and the northern Marquesas (Campbell, 1816; Hale, 1846), where mano took the value 4000 rather than 1000 . 


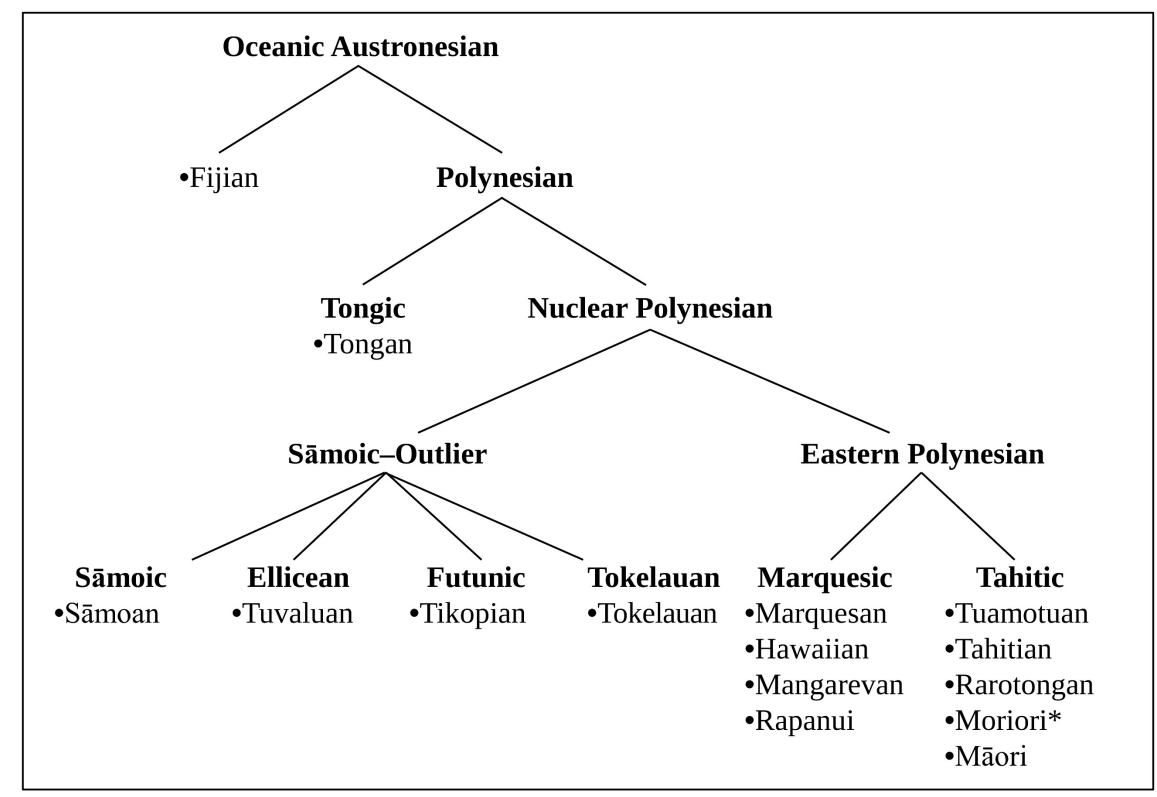

Figure 1. Polynesian languages

Notes. The languages shown represent the major linguistic groups and landmasses of the region. The language tree was constructed from several sources that differ somewhat in the details of linguistic relatedness; thus, the image represents how the Polynesian languages shown in Table 1 are generally related. The language relations also correspond in large part to the geographic distribution of the island groups and the approximate order of their settlement. Key. An asterisk (*) means the language is extinct.

What is arguably the most unusual Polynesian elaboration of decimal counting has been found in Mangareva, which lies toward the eastern extent of the Polynesian migration. In one of two traditional methods of counting, instead of counting 10 groups of 10 to reach 100, the islanders used productive terms for 20, 40, and 80 as binary steps (Bender \& Beller, 2014; also see Figure 2).

Why did the Polynesians develop specified and collective counting or the unusual and interesting binary steps? One explanation, proposed by Bender and Beller $(2014,2018)$, was that such strategies were cognitively efficient means of calculating mentally "in the absence of notation”" (Bender \& Beller, 2014, p. 1323). These authors assessed how number-words in Polynesian languages like Tongan and Western languages like English affected the performance of

\footnotetext{
${ }^{4}$ As a category, notation can be broadly construed to encompass both written numerals and artifacts like tallies that act as reference sets for enumerated objects. However, it is important to separate the roles of manipulation (as in calculating) and recording (as in the results of calculation) and note that few material forms do both equally well; while both of these functions are important in elaborating numbers as a relational system, the former is critical to explicating relations between numbers, the latter to documenting them in ways they can be learned and applied.
} 
mental arithmetic. They compared features like word length, compositional regularity, and order and considered the total volume these presented to mental calculation, activity requiring the active mental manipulation or storage and later recall of algorithms performed with verbal numbers (Bender \& Beller, 2007, 2014, 2017). Shorter length, greater regularity, and predictable order are thought to facilitate the acquisition and comprehension of number-words and numerical structure and organization (Cantlon \& Brannon, 2007), as well as reduce demands on cognitive resources like working memory; both effects would be advantageous for learning numbers and performing mental arithmetic with number-words (Bender, Schlimm, \& Beller, 2015). Similarly, counting collectively condenses the numerical amounts needing representation and manipulation in mental calculation, and binary steps make mental calculation easier because the relation is so simple.

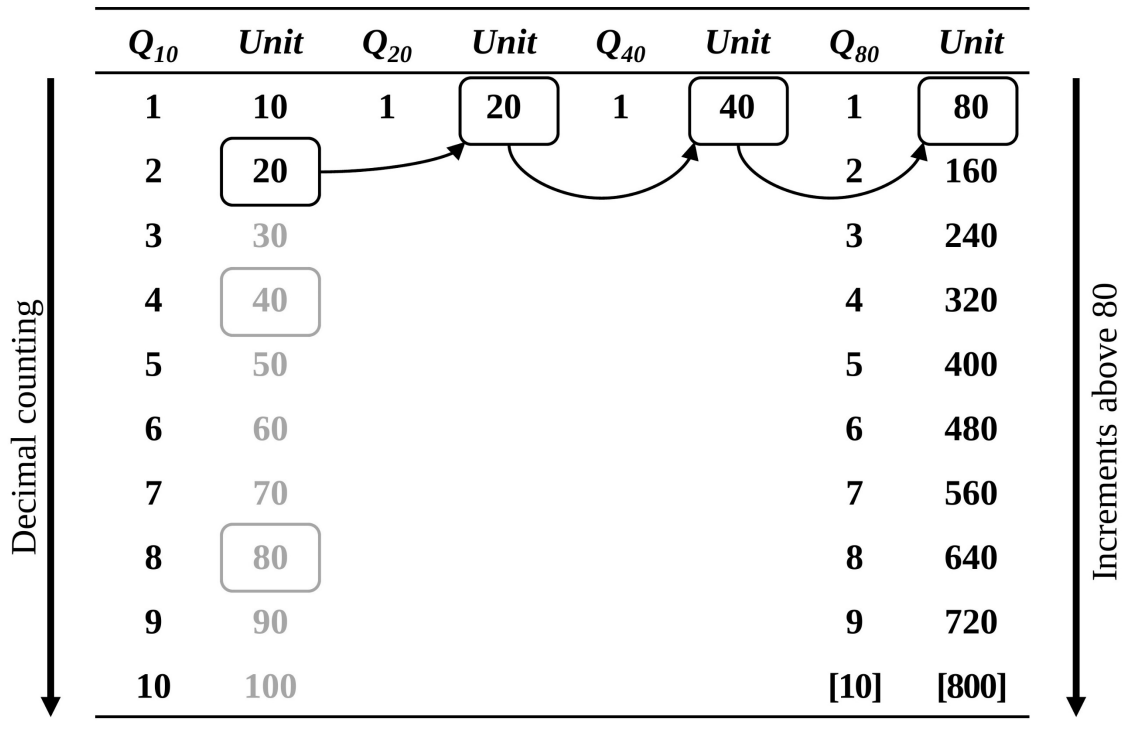

Figure 2. Mangarevan binary steps

Notes. Where decimal counting accumulates 10 groups of 10 to form 100, Mangarevan binary counting forms groups at 20 (paua), 40 (tataua), and 80 (varu, which also means eight), capitalizing on their relatedness by a factor of two (Bender, 2013; Bender \& Beller, 2014).

Without denying their advantages for calculating mentally, at least with relations and algorithms consistent with multiple counting sequences and traditional counting practices, it 
nonetheless seems unlikely that specified counting, collective counting, and binary steps developed for the purpose of performing arithmetic mentally. First, the resultant number-words are not clearly advantageous in terms of the characteristics thought to affect the mental manipulation of numbers. Polynesian number-words in specified counting systems can be longer than those in general counting, a potential disadvantage for mental calculation, though this can be mitigated or offset by the use of shortened or abbreviated forms whose meaning is understood in context (e.g., if yams are being counted, shortened forms are understood as referring to yams). Further, the regularity of Polynesian number-words for specified counting is comparable to the regularity of both the number-words of the associated general counting system, as well as the number-words of languages like English, showing no clear advantage in this feature.

Second and critically, in the several centuries of European contact, no observations documented the performance of mental arithmetic in the way tested and proposed as explanatory (e.g., arithmetic tasks like " $273+219$ ”; see Bender \& Beller, 2014, p. 1325). What early explorers did record included counting to impressively high numbers, regular exponential structure, different ways of counting different types of objects, the ability to combine and shift between different ways of counting, rounding off values smaller than the most significant digit, equivalences between amounts like twenty singles, ten pairs, and five fours realized by counting different types of objects differently, and regional homogeneity in counting words and practices. While quantities like million were unlikely to represent physical counting, their presence need not imply the use of Western-style addition to achieve such amounts, as they might more parsimoniously have reflected "merely a continuation of naming multiples" (Hiroa, 1938, p. 417). Given widespread practices of rounding, addition would then have been a matter of adding like units: In Tonga, four afe added to six afe would have made 10 afe, with 10 afe being equal to one mano; four afe added 
to six mano would simply have made six mano and four afe.

Third, practical considerations of counting objects with substantial physical weight and size in large quantities would have motivated the refinement of counting methods to gain physical and mental efficiencies, independent of - and likely prior to - any use in mental calculation. Physical efficiencies would have meant handling objects in a way that kept size constant (i.e., rather than creating bundles with increasingly large size and weight) and limited most objects to being handled only once (rather than handling most items multiple times in creating increasingly large bundles). Mental efficiencies would have involved things like minimizing number-words and using material devices to represent the count, thereby reducing demands on cognitive processes like attention and working memory. How the Polynesian counting sequences incorporated these efficiencies is explained below.

Implicit to the idea of counting or calculating mentally and without notations are two assumptions: first, that no artifactual form of any kind is used (Bender \& Beller, 2007, 2014), and second, that language is the sole or a primary vehicle for numerical concepts (Chomsky, 2004; Hurford, 2007). Initially, Polynesian numbers may give the appearance of existing only as number-words and being manipulated only mentally, given that the Polynesians did not develop notations prior to European contact (but see Note 2). However, it is not the case the Polynesians used no material devices whatsoever. Artifacts like tallies and stones have been documented throughout Polynesia and, as will be described, the enumerated objects themselves were manipulated during counting in ways resembling an abacus. Given the many physical and mental efficiencies of abacus-counting, specialized vocabulary and cognitive advantageousness would then have emerged as benefits, not teleological imperatives, of practical considerations in handling objects in order to count them. 
This conclusion draws on practical insights into counting physical objects in bulk, and a comparative analysis of the various ways such counting can be performed: verbally, with or without the manipulation of the objects being counted, with or without a method of recording, and with or without adjustments to the counting words used. For example, counting to tens by words alone, let alone hundreds and thousands, is not the easiest way to count things, since as numbers become higher, the associated number-words become longer and more complex (e.g., "six thousand, nine hundred, and two; six thousand, nine hundred, and three; six thousand, nine hundred, and four"; etc.). Verbal counting to large quantities, especially if unassisted by any material form of keeping track of the count, imposes a significant demand on cognitive resources (e.g., attention and working memory). Relative to counting with material forms, counting with words alone is more vulnerable to interruption. Counting without manipulating the enumerated objects is further challenged by their lack of visual distinguishability, if they are not rearranged or indicated in some fashion, as this is implicit to the perceptual experience of quantity (i.e., quantities over three or four are perceived as "many"; see Dehaene, 2011; Piazza, 2011).

Such drawbacks quickly offset the linguistic advantages ascribed to Polynesian counting. These considerations suggest that non-linguistic factors may have informed or motivated the development and use of techniques like specified counting, collective counting, and binary steps. The alternative view adopted here takes the manuovisual engagement of material forms as one of two interdependent, co-influential, and ultimately distinct means of accessing and elaborating human numerical intuitions, the other being language (Overmann, 2018). On this view of numerical cognition, the kinds of elaborations found in Polynesian decimal counting should have a material basis, one consistent with the available linguistic, structural, behavioral, and cultural data, as well as change associated with progressive settlement. That basis is described below. 


\section{The material roots of Polynesian numbers}

Polynesians are known for their impressive counting. Counting into the hundreds, thousands, and even higher occurred in contexts of gifting and celebrating. Yet counting hundreds or thousands of anything with words has drawbacks, as previously mentioned, while counting things by hand costs physical effort and time, often considerable. The latter is particularly true for items like coconuts that weigh several pounds each. The numbers produced also seem to have been ceremonial items, in that they do not appear to have been recorded anywhere, as they presumably would, if the point of counting were to manage resources numerically rather than celebrate surplus. While no notations and few if any permanent counting artifacts were involved, the enumerated objects — things like yams and coconuts and fish — were handled in the process of counting them. Counting a lot, counting often, and counting by handling the objects without producing overt notations or involving permanent counting artifacts form the basic parameters of Polynesian counting.

Additional parameters are suggested by $19^{\text {th }}$-century descriptions of Polynesian counting practices, as well as the numbers themselves: counting practices were extensible to collective units, influencing the structure and organization of Polynesian number-words in particular ways (e.g., equivalences, polyvalence, and upward shifts). Counting remained thoroughly decimal, preferentially counting from one to ten and influencing the points at which productive terms occurred. Finally, any counting and calculation would leverage the relations between numbers explicated by the material forms used to represent and manipulate numbers.

Reconstructing a method of counting consistent with these parameters and capable of producing binary steps like those of Mangareva required looking beyond Mangareva itself to all of Polynesia. This is because there were few historical descriptions of Mangarevan counting 
practices, but more when Polynesia was considered more widely. Mangareva also lies at Polynesia's eastern periphery, positioning it toward the end of changes associated with progressive settlement and suggesting its structure and organization had their roots in the older numerical systems. A challenge in using data from all of Polynesia was that early observers could be inconsistent in what they recorded and occasionally misunderstood what they witnessed. ${ }^{5}$ Nonetheless, their descriptions attested to the use of specified and collective counting throughout Polynesia. Crucially, descriptions showed these practices as related and homogeneous, paralleling the homogeneity of and linguistic affinities between Polynesian numerical vocabularies. That is, while Polynesian counting practices differed somewhat in their local details, particularly toward the eastern periphery, they showed more overall similarity than particular variability.

Adjusting counting methods toward greater physical and mental efficiency is intuitive. As was once noted for the Tongans, "a people who are in the frequent habit of counting out yams, \&c. to the amount of one, two, or three thousand, must become tolerably good numerators, by finding out some method of rendering the task of counting more easy" (Martin, 1818, p. 370). Call it a preference for making things easier or an evolutionary imperative to conserve calories, working smarter and not harder is arguably one of the reasons that humans are so creative a species. Yet implicit to Polynesian number-words is the idea of forming bundles of increasingly larger size: scores, or groups of 10 pairs; 10 -scores, or 10 groups of scores; 100-scores, or 10 groups of 10-scores; and so on. Such bundling would increase the physical effort and time involved in counting, often to the point where bundle size and volume would become disadvantageous, if not infeasible. An average coconut weighs about 3 pounds, with 10 nuts

\footnotetext{
${ }^{5}$ A few of these instances are (in)famous, as for example, the Tongan number-words reported by Jacques Labillardière (1800) and their exposure as spurious (and obscene) by Martin (1818). 
weighing 30 pounds, 100 nuts 300 pounds, and 1000 nuts a whopping 3000 pounds. ${ }^{6}$ Weight on this scale - not to mention the sizes involved, as unhusked coconuts can reach up to 18 inches in length and 12 inches in circumference-would tend to preclude counting by gross bundling. Individual items would also need to be handled multiple times, as each nut in a bundle of 1000 nuts would have already been handled in forming bundles of tens and hundreds; this too would increase the associated physical workload.

So how might counting be performed without creating large and heavy physical bundles? Tongan ceremonial counting (Table 2a) offered a suggestion:

Presentations of food and kava are brought and placed before the king and chiefs. These are arranged in orderly rows, pigs, yams, etc., and kava, so as to be easily viewed. ... [Counting] is done by a man who walks along the rows of baskets, touching each in turn and counting in a loud voice. When he reaches ten a second man jumps up, holding a staff, and calls "one"; the first man continues counting to twenty, when the second man shouts "two," and so on up to one hundred, when the second man calls "ten," and a third man gets up, holding a staff, and shouts "one." So they go on, the first man actually counting, the second keeping count of the tens, and the third of the hundreds. Should the number of baskets go into the thousands a fourth man would join in. When the counting is finished the result is formally announced" (Collocott, 1927, p. 26).

This interesting artifact - an ephemeral abacus with human rods and verbal/behavioral beadswas a highly ritualized form of finger-counting using the hands of several people. It was used in

\footnotetext{
${ }^{6}$ It is difficult for the average human (of either sex) to lift more than half their body weight, even assuming optimal fitness. This amount would still be less than the 300 pounds a bundle of 100 nuts would weigh. Bulk would also be an obstacle to gross bundling, as unhusked coconuts can reach 18 inches (tip-to-tip length) and 12 inches (circumference).
} 
Fiji as well, though without ceremonial connotations, as attested by the term bunuca, "to tally, or count the number of tens while another is counting the units, as in counting yams, etc." (Hazlewood, 1850, p. 20). Participants counted from one to ten, with the recruitment of new participants signifying the attainment of larger virtual bundles, the higher exponential registers. No physical bundles were created or moved, nor did items even need to be handled, apart from their placement in rows for the purpose of display. The counting device itself persisted no longer than the enumeration did and disappeared without trace when counting was finished.

This Fijian-Tongan collaborative counting also illustrates the principle that one way of making counting easier is to reduce it to a matter of repetitively counting from one to ten. This has the effect of reducing the complexity of the number-words involved, since they retain their limited range (i.e., one through ten), rather than acquiring the increased complexity needed to represent multiples of ten, hundreds, thousands, and higher. While the limited range would reduce the demand on cognitive resources, it would also necessitate the use of an external method of keeping track of accumulation (e.g., how many tens) and register shifts (e.g., when the tenth 10 becomes 100). In the Fijian-Tongan method, the man counting the items counted from one to ten, while another man accumulated the number of tens, and the involvement of the third man tracked the shift to hundreds. This straightforward counting method also suggested that subsequent Polynesian numerical elaborations might similarly involve repetitive counting from one to ten.

Another way to make counting easier is handling the objects collectively (Table $2 \mathrm{~b}$ and 2d), a practice found throughout Polynesia. Many of the objects enumerated, "being articles of food, and of small size (such as yams, cocoa-nuts, fish, and the like), can be most conveniently and expeditiously counted in pairs. ... Taking one in each hand, the native, as he throws them 
Table 2. Comparison of four Polynesian counting methods.

\begin{tabular}{|c|c|c|c|c|c|c|c|}
\hline \multicolumn{8}{|c|}{ a. Counting to 4627 in singles by tens (Fijian-Tongan method) } \\
\hline 4627 singles & Remainder & & 4 1000-bundles & $x$ & 1000 & $=$ & 4000 \\
\hline 462 10-bundles & 7 singles & & 6 100-bundles & $\times$ & 100 & $=$ & 600 \\
\hline 46 100-bundles & 2 10-bundles & & 2 10-bundles & $\times$ & 10 & $=$ & 20 \\
\hline \multirow[t]{2}{*}{4 1000-bundles } & 6 100-bundles & & 7 singles & $\times$ & 1 & $=$ & 7 \\
\hline & 4 1000-bundles & & & & & & 4627 \\
\hline \multicolumn{8}{|c|}{ b. Counting to 4627 by pairs by tens (Tongan specified numbers for sugar cane) } \\
\hline $2313 \frac{1}{2}$ pairs & Remainder & & 2 afe & $\times$ & 2000 & $=$ & 4000 \\
\hline 231 tetula (10 pairs) & $3^{1 / 2}$ pairs & & 3 teau & $\times$ & 200 & $=$ & 600 \\
\hline 23 teau $(10$ tetula $)$ & 1 tetula & & 1 tetula & $\times$ & 20 & $=$ & 20 \\
\hline \multirow[t]{2}{*}{2 afe $(10$ teau $)$} & 3 teau & & $3 \frac{1}{2}$ pairs & $\times$ & 2 & $=$ & 7 \\
\hline & 2 afe & & & & & & 4627 \\
\hline \multicolumn{8}{|c|}{ c. Counting to 4627 using every tenth item as a counter (Māori "elevens" method) } \\
\hline 4627 singles & Counters & Remainder & & & & & \\
\hline 462 10-bundles & 462 counters & 7 singles & 4 1000-bundles & $x$ & 1000 & $=$ & 4000 \\
\hline 46 100-bundles & 46 counters & 2 10-bundles & 6 100-bundles & $\times$ & 100 & $=$ & 600 \\
\hline \multirow[t]{3}{*}{4 1000-bundles } & 4 counters & 6 100-bundles & 2 10-bundles & $\times$ & 10 & $=$ & 20 \\
\hline & & 4 1000-bundles & 7 singles & $\times$ & 1 & $=$ & 7 \\
\hline & & & & & & & 4627 \\
\hline \multicolumn{8}{|c|}{ d. Counting to 4627 by pairs using every tenth item as a counter (Māori-Hawaiian method) } \\
\hline $2313 \frac{1}{2}$ pairs & Counter & Remainder & & & & & \\
\hline 231 scores & 462 counters & $3 \frac{1}{2}$ pairs & 2100 -scores & $x$ & 2000 & $=$ & 4000 \\
\hline 23 10-scores & 46 counters & 1 scores & 3 10-scores & $x$ & 200 & $=$ & 600 \\
\hline \multirow[t]{3}{*}{2100 -scores } & 4 counters & 3 10-scores & 1 scores & $x$ & 20 & $=$ & 20 \\
\hline & & 2 100-scores & $3 \frac{1}{2}$ pairs & $\times$ & 2 & $=$ & 7 \\
\hline & & & & & & & 4627 \\
\hline
\end{tabular}

Notes. (a) Counting singly in groups of 10 forms increasingly larger bundles and requires repeatedly handling objects. An alternative based on collaborative finger-counting, Fijian bunuca and Tongan ceremonial counting, has the same functionality while eliminating bundles and repeated handling. (b) Counting by pairs, suggested by the Tongan system for counting sugar cane, reduces the workload by half. Its equivalence to the method shown as $2 \mathrm{~d}$ suggests it may have differed in the words used, not the counting method itself. (c) Setting aside every tenth item as a counter, as Māori were described as doing, reduces physical effort even further, since physical weights and volumes remain constant. (d) Counting collectively with counters (Figures 3 and 4) combines reduced handling with size constancy.

into the storehouse, or on to the heap, counts one; for two pairs, he says two; for ten pairs simply ten, and so on" (Hale, 1846, p. 247). Counting by pairs and fours reduces both the physical handling and time involved for counting, by half when counting by twos and to a fourth when counting by fours. Specific counting systems would then emerge, depending on whether specific objects or kinds were most conveniently counted singly or collectively. However, collective counting by verbal means, even if enumeration involves moving objects in the process of 
counting them, is prone to the drawbacks mentioned earlier, like increased demands on cognitive resources and vulnerability to interruption. Though differentiated here as a counting method for the purposes of this analysis, collective counting would likely have been combined with a method for keeping track of accumulations and register shifts, instead of relying on numberwords alone. Its equivalence to a method with counters (Table $2 \mathrm{c}$ and $2 \mathrm{~d}$ ) suggests that counting by twos and fours perhaps differed in the words and conceptual bundles used, as in the Tongan system for counting sugar cane, rather than functionally, in the manner of counting (with the exception of the base unit being collective, not single).

Māori, the inhabitants of New Zealand, were said to have counted by "putting aside one to every ten as a tally" (Williams, 1844, p. xv). This observation was later deemed erroneous, as it had been misunderstood to mean that Māori counted by "elevens"” (Conant, 1896, pp. 122123; also see analysis in Overman, 2020). Nonetheless, it documented the use of the enumerated objects themselves as "tallies" or counters, a practice that eliminated bundling and repetitive handling by making counting a matter of sorting, which reduced physical effort by maintaining constancy of size (Overmann, 2020).

The same method was described in decimal terms for Tikopia, a Polynesian outlier located in the Solomon Islands of Melanesia: the informant, using grains of rice to demonstrate, "reckoned nine and then put aside the 10th grain, and so on. Afterwards he reckoned up the tenth grains to reckon the hundreds" (Durrad, 1913, p. 46). The Tikopian language is classified as a Samoic-Outlier, giving it linguistic affinity with the oldest settled western part of Polynesia. This implies that the method of counting with counters was fairly old, something that would also account for its widespread distribution within Polynesia. A similar method of counting with

\footnotetext{
${ }^{7}$ It is indeed possible to set aside every $11^{\text {th }}$ item as a tally; the quantity is correctly enumerated, though in base 11 rather than decimal. It is unlikely the Polynesians did this, as "elevens" counting fails to yield the heuristics found throughout Polynesia, wherein twenty singles, ten pairs, and five fours were recognized as having equivalent value.
} 
counters has been observed in Papua New Guinea (Döhler, 2018; Evans, 2009; Williams, 1936; also see discussion in Overmann, 2020). This suggests that counting with counters may be old within Oceania, the region encompassing Polynesia, Melanesia, and Micronesia.

A different method was described for the Marshall Islands of Micronesia, which lie north and slightly west of Tuvalu: a stone was used to mark every 10 coconuts: "[E]r legt für zehn Kokosnüsse einen Stein als Marke hin” (Krämer, 1906, p. 438). Like sorting enumerated items into different piles, manuports like stones would have little visibility or persistence as artifactual forms. Nonetheless, both counting by setting aside items as counters and manuports are material enough to counter the impression that counting devices were not used in Polynesia. While the collection and use of stones might not have involved much physical effort, they would undoubtedly have added to the time required for counting into the hundreds and thousands. However, like the Tikopian counting method described by Durrad, the Marshall Islands use of stones suggests a decimal variation of the Māori counting misunderstood as involving "elevens."

Combining the two yields a method in which one of every 10 items is put aside as a tally (Table 2c). The use of counters maintains constancy of size, keeps track of accumulations and register shifts, and minimizes cognitive demands and the words required with repetitive 10counting. Counting objects collectively minimizes handling even further, producing an extremely efficient method of counting (Table 2d). Whether counting is performed with singles, pairs, or fours, enumerated objects are handled just once, except for the items set aside as counters and handled again in that capacity. With pairs (Figure 3), counters in the initial round of counting represent scores and are counted again at the next higher register-10-scores instead of scoresand are afterward simply added to the heap of counted objects as they too are expended. No material record is created, aside from the enumerated objects themselves in the process of 
counting, where they function as a self-effacing or ephemeral abacus.

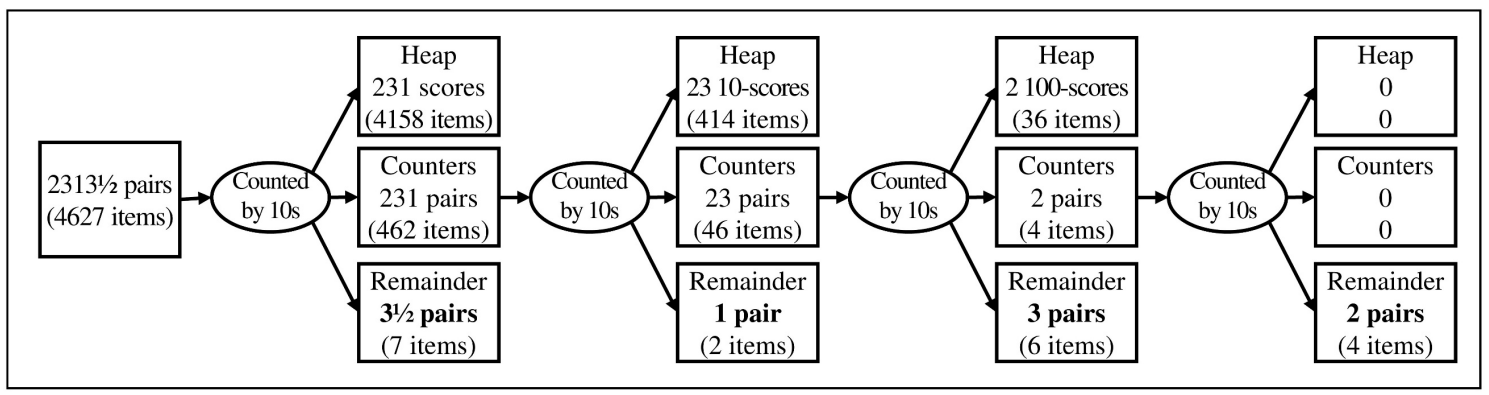

Figure 3. Counting in pairs with counters

Notes. In the first round, $2313 \frac{1}{2}$ pairs counted by tens create 231 scores, of which every tenth pair (231 pairs) is retained as a counter and 4158 items (nine of every 10 pairs) are added to the heap (the term used by Hale [1846] to describe the pile of objects created during enumeration); there is a remainder of $3 \frac{1}{2}$ pairs. In the second round, 231 pairs counted by tens create 2310 -scores, of which every tenth pair ( 23 pairs) is retained as a counter and 414 items (nine of every 10 pairs) are added to the heap; there is a remainder of one pair. In the third round, 23 pairs counted by tens create two 100-scores, of which every tenth pair (two pairs) is retained as a counter and 36 items (nine of every 10 pairs) are added to the heap; there is a remainder of three pairs. In the last round, two pairs remain. In modern notation, the algorithm produces anachronistic precision using the remainders $\left(3 \frac{1}{2}, 1,3\right.$, and 2$)$ multiplied appropriately: $[(2 \times$ $\left.2000)+(3 \times 200)+(1 \times 20)+\left(3 \frac{1}{2} \times 2\right)\right]$. However, words meaning remainder, like koena in Hawaiian (Andrews, 1836, p. 71), toènga in Tuamotuan (Stimson, 1964, p. 542), akatouara in Mangarevan (Tregear, 1899, p. 7), and tauwhara in Māori (Best, 1906, p. 166) suggest the amount might well have been understood as two virtual bundles worth 2000 each and a remainder (or two virtual bundles worth 1000 each and understood as doubled, plus a remainder). The method is easily extended to units of four and eight; with fours, $4627=[(1 \times 4000)+(1 \times 400)+(5 \times$ $40)+(63 / 4 \times 4)]$; with eights, $4627=[(5 \times 800)+(7 \times 80)+(8.375 \times 8)]$. Also see Table $2 \mathrm{~d}$.

Setting aside every tenth item while counting by pairs explains the curious Hawaiian word for twenty, iwakalua, "a word compounded of iwa, nine, and lua, two" (Hale, 1846, p. 248). This has long been a mystery, as Hale noted, "why it should have this meaning cannot well be understood" (p. 248). Iwakalua is, simply, counting to ten with pairs (numerically twenty), with nine pairs (or 18 items) counted and the last pair (two items) set aside for use as counters. Counting with counters may also explain terms like ageroa in Mangarevan, "an expression used before pronouncing the tenth in counting. Ex. Tai, rua, \&c., \&c. Ageroa e tai a rogouru" (Tregear, 1899, p. 1). Applied to collective counting, the use of counters would occasion productive terms at 10 of the counted unit, consistent with how such terms emerge in standard decimal systems. This explains the widespread prevalence of terms for 20 meaning ten twos 
(Tregear, 1899), the emergence in Hawaiian of a productive term at 40 (kanneha) meaning ten fours (Andrews, 1854; Campbell, 1816), and the emergence in Mangarevan of productive terms at 20, 40, and 80 (paua, tataua, and varu) meaning ten twos, ten fours, and ten eights (Janeau, 1908). Counting collectively with counters also shifted productive values upward, so 100 in general counting became 200 in pair-counting (Bender \& Beller, 2007); similarly, mano, 1000 in many Polynesian number systems, became 2000 when counting by pairs and 4000 when counting by fours (Hale, 1846; also see Table 3). These shifts could be understood contextually (e.g., counting breadfruit implied that counting was done by fours and the number as expressed in language would be multiplied by four). The shifts could also be accompanied by words and phrases that fixed numerical values by specifying the manner of counting: terms like tipau tahi and tipau rua (Janeau, 1908, p. 19) or tatau ta ki táhi and tatau ta ki dúa (Lee, 1820, p. 19) distinguished counting one-by-one from counting two-by-two, while terms like rogouru (Janeau, 1908, p. 19), rari takāu (Stimson, 1964, p. 489), and tauga differentiated twenty singles from takau, ten pairs (Tregear, 1899, pp. 92, 98). Terms also become polyvalent, differing in value by their context of use, like taha in Tongan meant one or two, depending on whether counting was done by singles or pairs (Bender \& Beller, 2007).

The productive terms at 20,40, and 80 are the Mangarevan binary steps (Figure 2 and Table 3), 10 of the unit when counting by twos, fours, and eights using counters. Counting with counters is easily adapted to incorporate the productive terms. Counting begins in the MāoriHawaiian manner by counting from one to ten and setting aside every tenth item as a counter (Figure 4). In the second round, instead of continuing to count decimally, counting proceeds by groups of eight. Every eight counters make one varu, likely explaining why the word eight is 
Table 3. Numerical structure in counting singly or collectively with pairs, fours, and eights

\begin{tabular}{|c|c|c|c|c|c|c|c|}
\hline \multicolumn{4}{|c|}{ a. Tongan (pairs) } & \multicolumn{4}{|c|}{ b. Hawaiian (fours) } \\
\hline $\mathrm{Nr}$. & General & $\mathrm{Nr}$. & Pairs & Nr. & General & $\mathrm{Nr}$. & Fours \\
\hline 1 & taha & 2 & taha & 1 & kahi & 4 & kauna \\
\hline 10 & hongofulu & 20 & tekau & 10 & $u m i$ & 40 & kannaha \\
\hline 100 & teau & 200 & tefua & & & 400 & lau \\
\hline 1000 & [taha] afe & 2000 & [taha] afe & & & 4000 & mano \\
\hline \multicolumn{8}{|c|}{ c. Mangarevan (twos, fours, and eights) } \\
\hline $\mathrm{Nr}$. & General & Nr. & Pairs & $\mathrm{Nr}$. & Fours & $\mathrm{Nr}$. & Eights \\
\hline 1 & tahi & 2 & tahi & 4 & tahi & 8 & tahi \\
\hline 10 & takau & 20 & takau & 40 & takau & 80 & takau \\
\hline 20 & paua & 40 & paua & 80 & paua & 160 & paua \\
\hline 40 & tataua & 80 & tataua & 160 & tataua & 320 & tataua \\
\hline 80 & varu & 160 & varu & 320 & varu & 640 & varu \\
\hline
\end{tabular}

Notes. Counting collectively with counters shifts productive points upward, (a) so 100 in Tongan general counting had the value 200 and (b) a new productive term emerged in Hawaiian at 40, meaning ten fours. (c) In Mangarevan, collective counting also included eight as a basic unit, creating a productive term at 80 (ten eights) and producing the three binary steps.

used to name the higher unit. Any fewer than eight might be called a remainder, consistent with Polynesian rounding generally and the round numbers used in noting an upper limit for binary counting $^{8}$ in particular (with the upper limit likely reflecting the fact that once counting proceeded by eights, it was no longer decimal). While quantities of ten varu and higher are both possible and namable, the lack of higher productive terms suggests the system's arithmetical applications were relatively circumscribed, with both outputs and any operands (assuming they were used but simply not recorded by observers) falling within the system's limit.

Elaborations similar to those underlying Mangarevan binary counting were also documented in Hawai' $i$ and likely occurred for the same reason, the availability of productive terms for 20 and 40 occasioned by collective counting with counters. The Hawaiian term for 40, kannaha, meant ten fours, while 80, arooa kannaha, was two forties (Campbell, 1816, p. 183).

\footnotetext{
${ }^{8}$ It is indeed possible to set aside every $11^{\text {th }}$ item as a tally; the quantity is correctly enumerated, though in base 11 rather than decimal. It is unlikely the Polynesians did this, as "elevens" counting fails to yield the heuristics found throughout Polynesia, wherein twenty singles, ten pairs, and five fours were recognized as having equivalent value.
} 


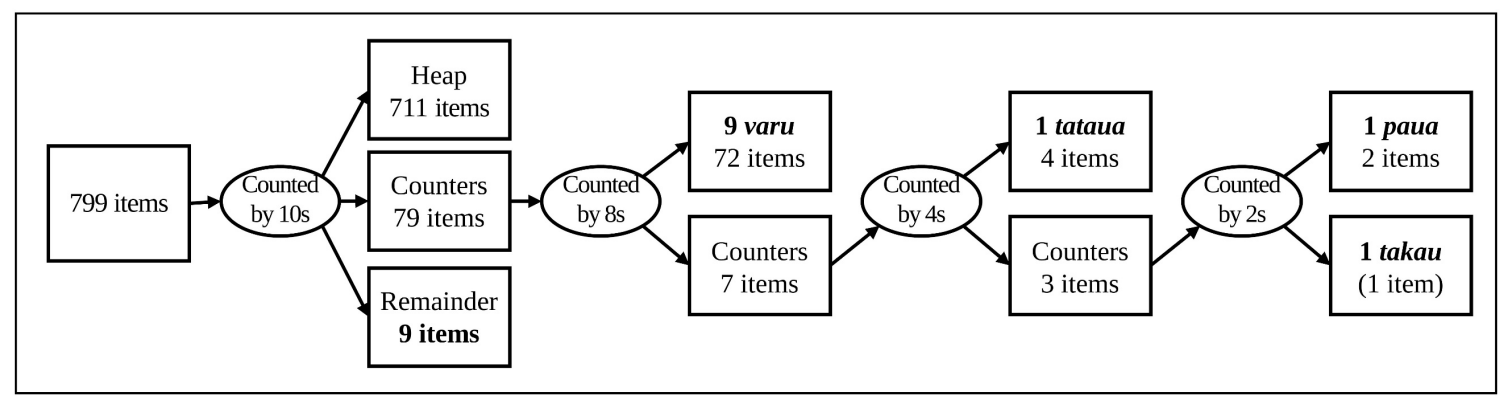

Figure 4. Mangarevan binary counting with counters

Notes. Seven hundred and ninety-nine items represent the upper limit as documented by Hiroa (1938) and Janeau (1908), as explained in Note 8. Sorting puts 711 items (nine of every 10 items) into the pile of counted items and 79 items (the tenth item of every 10 items) into the pile of counters, with nine items remaining. The 79 counters are then counted by eights to create nine varu (72 items). The amount could be expressed as nine varu with a remainder. The process could also be carried out further, improving the accuracy of the result, as the counting strategy merely rearranges the remaining items, rather than putting them through successive rounds of counting (as was the case in the algorithm shown in Figure 3). In this case, four of the remaining seven counters make one tataua, two make one paua, and one makes one takau, or nine varu, one tataua, one paua, one takau, and nine units $[(9 \times 80)+(1 \times 40)+$ $(1 \times 20)+(1 \times 10)+(9 \times 1)]$. When the unit is pairs, the method yields four varu, one tataua, one paua, one takau, and nine-and-a-half units, an amount understood as doubled. When the unit is fours, the result is two varu, one paua, one takau, and nine-and-three-quarter units, an amount understood as multiplied by four.

Ten kannaha made a lau, or 400; ten lau made a mano, 4000; ten mano made a kini, 40,000; and ten kini made a lehu, 400,000 (Andrews, 1854, p. 57). This system, like traditional number systems throughout Polynesia, appears to have largely supplanted by standard decimal counting, which was introduced by missionaries (Von Chamisso, 1837, p. 56). These felt themselves "obliged" to "induce the natives to return to the more convenient decimal enumeration" (Hale, 1846, p. 247), considered a "modern improvement" (Andrews, 1854, p. 57) over the ingenious traditional counting methods so poorly understood by Western observers. However, Hawaiians also recognized the economic, financial, and political advantages of adopting the foreign number system (Lagaro, 1842), so the replacement of traditional numbers was not unilaterally imposed.

Besides collaborative finger-counting and the enumerated objects themselves, the Polynesians used other material forms for counting, though most were forms that tend not to preserve as material culture: In Tikopia, pieces of coconut leaf were used as a mediating device in 
counting hillocks made in planting yam, improving accuracy relative to counting "by eye alone" (Firth, 1940, p. 187). On Rapa Nui, notches in a door post both counted and recorded days spent in a house (Routledge, 1920, p. 444). In the context of counting hundreds or thousands of items, either would add to the time required for enumeration. Marks on the ground may also have been used for both counting and calculation, as the word helu, found in many Polynesian dialects as a word for counting (Mosblech, 1843, p. 23), in Hawaiian meant "to paw the ground as an angry bull, to dig potatoes with the fingers, to scratch the earth as a hen, to count, number, to compute" (Andrews, 1836, p. 40, emphasis added). These connotations imply the use of marks in counting, perhaps to track accumulations and register shifts in the manner of Fijian-Tongan collective counting, and possibly also in computing, where they might have aided the visualization of outputs and operands (again noting there are no witnessed descriptions of this having occurred).

\section{Conclusion}

Polynesian elaborations of decimal numbers show how the material forms used to represent and manipulate quantity—and their manuovisual engagement—can influence numerical structure and organization, as well as linguistic labels. Certainly, without their material component, terms like iwakalua are difficult to comprehend, and the multiple counting sequences and their polyvalent terms remain oddly disconnected. Yet numbers are so thoroughly identified with language that the material forms used have become all but invisible, except perhaps for ones considered embodied, like the fingers when used to count, or symbolic, like written numerals. In this study, looking for the material basis of traditional Polynesian numbers realized unique insights that language was unable to provide on its own. This suggests that it is time to admit materiality and its manuovisual engagement into the cognitive system for numbers. 
Admitting materiality into the cognitive system for numbers does not imply jettisoning language, for its contributions are both well established and many. Rather, there are advantages in viewing numerical cognition as a system with two ways of accessing and elaborating numerical intuitions, one linguistic and the other manuovisual, that if distinct are nonetheless interdependent and co-influential. Their mutual influence is highlighted by the likelihood that verbal labels for productive terms at 20,40, and 80 were critical enablers of Mangarevan developments of binary methods for counting and calculation.

Most importantly, numerical qualities deemed cognitively advantageousness appear to originate as behaviors with material forms intended to reduce physical and mental effort. The physical component in particular may be more than just using material forms to decrease demands on cognitive resources. Counting is inherently physical, as counting without manipulating-"by eye alone" (Firth, 1940, p. 187) - is more difficult and less accurate, as it is constrained by the way quantity is perceived. The physical component of counting evokes the neural activity seen during numerical processing tasks. This activity appears to depend at least as much on planning motor movements, grasping and manipulating objects, appreciating relations and patterns visually, and non-verbal reasoning (Amalric \& Dehaene, 2016; Frank \& Barner, 2012; Ranzini et al., 2011; Vandervert, 2017) as it does being able to express ideas in language. Cognitive advantageousness in verbal forms of number may then be a property of fit with the operation of this neural machinery. This possibility will hopefully be examined through future research.

These matters have greater potential interest and research utility than merely explaining historical curiosities like counting by "elevens" and why nine and two make twenty. They suggest that understanding numbers means looking beyond language and admitting the domain of material forms used in representing and manipulating into investigations of numerical cognition. 


\section{Acknowledgements}

This project has received funding from the European Union's Horizon 2020 research and innovation program under grant agreement No. 785793. Thanks are also due to Andrea Bender for comments on an early draft.

\section{References}

Alexander, W. D. (1864). A short synopsis of the most essential points of Hawaiian grammar. 1891 print. Honolulu, HI: Press Publishing Company.

Amalric, M., \& Dehaene, S. (2016). Origins of the brain networks for advanced mathematics in expert mathematicians. Proceedings of the National Academy of Sciences of the United States of America, 113(18), 4909-4917.

Andrews, L. (1836). A vocabulary of words in the Hawaiian language. Lahainaluna, HI: Press of the High School.

Andrews, L. (1854). Grammar of the Hawaiian language. Honolulu, HI: Mission Press.

Audran, H. (1920). Traditions of and notes on the Paumotu (or Tuamotu) Islands. Part VI. Journal of the Polynesian Society, 29(113), 42-43.

Beller, S., \& Bender, A. (2005). The cognitive advantages of counting specifically: an analysis of Polynesian number systems. Proceedings of the Annual Meeting of the Cognitive Science Society, 27, 214-219.

Bender, A. (2013). Two accounts of traditional Mangarevan counting ... and how to evaluate them. Journal of the Polynesian Society, 122(3), 275-287.

Bender, A., \& Beller, S. (2007). Counting in Tongan: the traditional number systems and their cognitive implications. Journal of Cognition and Culture, 7(3), 213-239.

Bender, A., \& Beller, S. (2014). Mangarevan invention of binary steps for easier calculation. Proceedings of the National Academy of Sciences of the United States of America, 111(4), 1322-1327.

Bender, A., \& Beller, S. (2017). The power of 2: how an apparently irregular numeration system facilitates mental arithmetic. Cognitive Science, 41(1), 158-187.

Bender, A., \& Beller, S. (2018). Numeration systems as cultural tools for numerical cognition. In D. B. Berch, D. C. Geary, \& K. M. Koepke (Eds.), Mathematical cognition and learning (Vol. 4, pp. 297-319). Amsterdam, The Netherlands: Academic Press.

Bender, A., Schlimm, D., \& Beller, S. (2015). The cognitive advantages of counting specifically: a representational analysis of verbal numeration systems in Oceanic languages. Topics in Cognitive Science, 7(4), 552-569.

Besnier, N. (1999). Tuvaluan: a Polynesian language of the Central Pacific. Abingdon, UK: Routledge.

Best, E. (1906). Māori numeration: some account of the single, binary, and semi-vigesimal 
systems of numeration formerly employed by the Māori. Transactions and Proceedings of the New Zealand Institute, 39, 150-180.

Best, E. (1907). Māori numeration: the vigesimal system. Journal of the Polynesian Society, $16(2), 94-98$.

Buzacott, A. (1854). Te akataka reo Rarotonga, or, Rarotongan and English grammar. Rarotonga: Mission Press.

Campbell, A. (1816). A voyage round the world, from 1806 to 1812; in which Japan, Kamschatka, the Aleutian Islands, and the Sandwich Islands were visited. New York, NY: Broderick and Ritter.

Cantlon, J. F., \& Brannon, E. M. (2007). Adding up the effects of cultural experience on the brain. Trends in Cognitive Sciences, 11(1), 1-4.

Charpentier, J.-M., \& François, A. (2015). Atlas linguistique de la Polynésie française. Berlin: Walter De Gruyter GmbH and Université de la Polynésie française.

Chomsky, N. (1988). Language and problems of knowledge: the Managua lectures. Cambridge, MA: MIT Press.

Chomsky, N. (2004). The generative enterprise revisited: discussions with Riny Huybregts, Henk van Riemsdijk, Naoki Fukui and Mihoko Zushi (2nd ed.). Berlin: Mouton de Gruyter.

Clark, A., \& Chalmers, D. J. (1998). The extended mind. Analysis, 58(1), 7-19.

Clark, E. W. (1839). Hawaiian method of computation. The Hawaiian Spectator, 2(1), 91-94.

Collocott, E. E. V. (1927). Kava ceremonial in Tonga. Journal of the Polynesian Society, 36(1), 21-47.

Conant, L. L. (1896). The number concept: Its origin and development. New York, NY: Macmillan and Co.

Crook, W. P. (2007). An account of the Marquesas Islands, 1797-1799. (G. Dening, H.-M. Le Cleac'h, D. Peacocke, \& R. Koenig, Eds.). Papeete, Tahiti: Haere Po.

Davies, J. (1851). A Tahitian and English dictionary, with introductory remarks on the Polynesian language, and a short grammar of the Tahitian dialect. Tahiti: London Missionary Society's Press.

Davletshin, A. (2012). Numerals and phonetic complements in the "Kohau Rongorongo" script of Easter Island. Journal of the Polynesian Society, 121(3), 243-274.

De Labillardière, J. J. H. (1800). Vocabulary of the language of the Friendly Islands. In Voyage in search of la Pérouse. Translated from the French (Vol. II, pp. 47-58). London: John Stockdale.

Dehaene, S. (2011). The number sense: how the mind creates mathematics (Revised ed.). Oxford: Oxford University Press.

Deighton, S. (1889). A Moriori vocabulary. In Appendices to the Journals of the House of Representatives (Vol. II, G-5, pp. 1-7). Wellington, NZ: George Didsbury. Retrieved from https://atojs.natlib.govt.nz/ 
Döhler, C. (2018). A grammar of Komnzo. Berlin: Language Science Press.

Dordillon, R. I. (1857). Essai de grammaire de la langue des Îles Marquises. Valparaiso: Imprimerie du Commerce.

Dreyfus, T. (1991). Advanced mathematical thinking processes. In D. Tall (Ed.), Advanced mathematical thinking (pp. 25-41). New York, NY: Kluwer.

Durrad, W. J. (1913). A Tikopia vocabulary. Journal of the Polynesian Society, 22(86), 86-95.

Ellis, W. (1826). Narrative of a Tour through Hawaii, or Owhyhee; with Observations on the Natural History of the Sandwich Islands, and Remarks on the Manners, Customs, Traditions, History, and Language of their Inhabitants. London: H. Fisher, Son, and P. Jackson.

Englert, S. (1977). Idioma Rapanui: gramatica y diccionario de antiguo idioma de la Isla de Pascua (2nd ed.). Santiago, Chile: Ediciones de la Universidad de Chile.

Evans, N. (2009). Two pus one makes thirteen: senary numerals in the Morehead-Maro region. Linguistic Typology, 13(2), 321-335.

Firth, R. (1940). The work of the gods in Tikopia. London: London School of Economics and Political Science.

Fischer, S. R. (1997). Rongorongo: the Easter Island script. Oxford: Clarendon Press.

Frank, M. C., \& Barner, D. (2012). Representing exact number visually using mental abacus. Journal of Experimental Psychology: General, 141(1), 134-149.

Fuentes, J. (1960). Diccionario y gramática de la lengua de la Isla de Pascua. Santiago, Chile: Editorial Andres Bello.

Giaquinto, M. (2007). Visual thinking in mathematics: an epistemological study. Oxford: Oxford University Press.

González de Haedo, D. F. (1770). The voyage of Captain Don Felipe Gonzalez in the ship of the line San Lorenzo, with the frigate Santa Rosalia in company, to Easter Island in 17701771. (B. G. Corney, Ed.). Cambridge: Hakluyt Society.

Guérin, V. (2017). The Oceanic subgroup of the Austronesian language family. In A. Y. Aikhenvald \& R. M. W. Dixon (Eds.), The Cambridge handbook of linguistic typology (pp. 911-941). Cambridge: Cambridge University Press.

Hale, H. (1846). United States exploring expedition. During the years 1838, 1839, 1840, 1841, 1842. Under the command of Charles Wilkes, U.S.N. Vol. IV, Ethnography and philology. Philadelphia, PA: C. Sherman.

Handy, E. S. C. (1923). The native culture in the Marquesas. Honolulu, HI: Bishop Museum.

Hazlewood, D. (1850). A Feejeean and English dictionary: with examples of common and peculiar modes of expression, and uses of words. Vewa, Feejee: Wesleyan Mission Press.

Henrich, J. (2004). Demography and cultural evolution: how adaptive cultural processes can produce maladaptive losses - the Tasmanian case. American Antiquity, 69(2), 197-214.

Hiroa, T. R. (1938). Ethnology of Mangareva. Honolulu, HI: Bishop Museum.

Hurford, J. R. (1987). Language and number: the emergence of a cognitive system. Oxford: 
Blackwell.

Hurford, J. R. (2007). The origins of meaning: language in the light of evolution. Oxford: Oxford University Press.

Hutto, D. D. (2013). Radically enactive cognition in our grasp. In Z. Radman (Ed.), The hand, an organ of the mind: what the manual tells the mental (pp. 227-252). Cambridge, MA: MIT Press.

Ifrah, G. (1981). The universal history of computing: from the abacus to the quantum computer. (R. Laffont, Trans.). New York, NY: John Wiley \& Sons.

Janeau, V.-F. (1908). Essai de grammaire de la langue des Iles Gambier ou Mangaréva par les Missionnaires catholiques de cet Archipel, membres de la Congrégation des SacrésCours de Picpus. Braine-le-Comte, Belgium: Imprimerie Zech et Fils.

Kaeppler, A. L. (1987). Spontaneous choreography: Improvisation in Polynesian dance. Yearbook for Traditional Music, 19, 13-22.

kake. (2019). Wehewehe Wikiwiki Hawaiian Language Resource. Retrieved from https://hilo.hawaii.edu/wehe/?q=kake

Kamali ‘i, K. B. (Ed.). (1983). The Hawaiian language. In Native Hawaiians study commission: report on the culture, needs and concerns of Native Hawaiians pursuant to Public Law 96565, Title III (Vol. I, pp. 173-203). United States: Native Hawaiians Study Commission.

Kaput, J. J. (1987). PME XI algebra papers: a representational framework. In E. Par, J. C. Bergeron, N. Herscovics, \& C. Kieran (Eds.), Proceedings of the 11th Psychology of Mathematics Education (PME) International Conference (Vol. 1, pp. 345-354). Montreal, Canada: The International Group for the Psychology of Mathematics Education.

Krämer, A. (1906). Hawaii, Ostmikronesien und Samoa: meine zweite Südseereise (1897-1899) zum Studium der Atolle und ihrer Bewohner. Stuttgart: Strecker \& Schröder.

Lagaro, N. (1842). Ka waiwai o ka helu [The value of the number]. Ka Nonanona, 2(10), 46-47. Retrieved from http://ulukau.org/collect/nupepa/index/assoc/HASHc029.dir/004_0_002_ 010_046_01_ful_18421011.pdf

Lee, S. (1820). A grammar and vocabulary of the language of New Zealand. London: Church Missionary Society.

Locke, J. (1690). An essay concerning human understanding (1854 print). Philadelphia, PA: Hayes \& Zell.

Lynch, J., Ross, M., \& Crowley, T. (2011). The Oceanic languages (Vol. 1). London: Routledge.

Malafouris, L. (2013). How things shape the mind: a theory of material engagement. Cambridge, MA: MIT Press.

Martin, J. (1818). An account of the natives of the Tonga Islands, in the South Pacific Ocean. With an original grammar and vocabulary of their language. Compiled and arranged from the extensive communications of Mr. William Mariner, several years resident in those islands (Vol. II). London: John Murray.

Maunsell, R. (1842). A grammar of the New Zealand language. Auckland, NZ: J. Moore. 
McLean, M. E. (1961). Oral transmission in Maori music. Journal of the International Folk Music Council, 13, 59-62.

McLean, M. E. (1977). Innovations in Waiata style. Yearbook of the International Folk Music Council, 9, 27-37.

Menninger, K. (1992). Number words and number symbols: a cultural history of numbers. (P. Broneer, Trans.). New York, NY: Dover Publications, Inc.

Mosblech, B. (1843). Vocabulaire Océanien-Français et Français-Océanien des dialectes parlés aux îles Marquises, Sandwich, Gambier, etc. Paris: Jules Renouard et Cie.

Nelsen, R. B. (1993). Proofs without words: exercises in visual thinking (Vol. 1). Washington, DC: The Mathematical Association of America.

Overmann, K. A. (2016a). Materiality in numerical cognition: Material Engagement Theory and the counting technologies of the Ancient Near East. DPhil thesis, University of Oxford, Oxford.

Overmann, K. A. (2016b). The role of materiality in numerical cognition. Quaternary International, 405, 42-51.

Overmann, K. A. (2018). Constructing a concept of number. Journal of Numerical Cognition, $4(2), 464-493$.

Overmann, K. A. (2019). The material origin of numbers: Insights from the archaeology of the Ancient Near East. Piscataway, NJ: Gorgias Press.

Overmann, K. A. (2020). The curious idea that Māori once counted by elevens, and the insights it still holds for cross-cultural numerical research. Journal of the Polynesian Society, 129(1), 59-84.

Piazza, M. (2011). Neurocognitive start-up tools for symbolic number representations. In S. Dehaene \& E. Brannon (Eds.), Space, time and number in the brain: searching for the foundations of mathematical thought (pp. 267-285). San Diego, CA: Academic Press.

Pratt, G. (1862). A Samoan dictionary: English and Samoan and Samoan and English; with a short grammar of the Samoan dialect. London: Missionary Society's Press.

Rabone, S. (1845). A vocabulary of the Tonga language: arranged in alphabetical order, to which is annexed a list of idiomatical phrases. Vava'u, Tonga: Wesleyan Mission Press.

Ranzini, M., Lugli, L., Anelli, F., Carbone, R., Nicoletti, R., \& Borghi, A. M. (2011). Graspable objects shape number processing. Frontiers in Human Neuroscience, 5, 147.

Rieth, T., \& Cochrane, E. E. (2018). The chronology of colonization in remote Oceania. In E. E. Cochrane \& T. L. Hunt (Eds.), The Oxford handbook of prehistoric Oceania (pp. 133161). Oxford: Oxford University Press.

Roussel, H. (1908). Vocabulaire de la langue de l'Île-de-Pâques ou Rapanui. Louvain, Belgium: J.-B., Istas.

Routledge, K. M. (1920). Survey of the village and carved rocks of Orongo, Easter Island, by the Mana Expedition. Journal of the Royal Anthropological Institute of Great Britain and Ireland, 50, 425-451.

Shand, A. (1895). The Moriori people of the Chatham Islands: their traditions and history. Chap.

Journal of Mathematics and Culture 
VII.-Ko Matangi-ao-(continued). The story of Tu-moana. Journal of the Polynesian Society, 4(4), 209-225.

Simona, R. (1986). Tokelau dictionary. Apia, Western Samoa: Office of Tokelau Affairs. Retrieved from www.thebookshelf.auckland.ac.nz/docs/TokelauDictionary/tokelau011.pdf

Stimson, J. F. (1964). A dictionary of some Tuamotuan dialects of the Polynesian language. Salem, MA: Peabody Museum.

Tregear, E. (1895). A Paumotuan dictionary with Polynesian comparatives. Wellington, NZ: Whitcombe \& Tombs, Ltd. and R. Coupland Harding.

Tregear, E. (1899). A dictionary of Mangareva (or Gambier Islands). Wellington, NZ: John MacKay, Government Printing Office.

Vandervert, L. R. (2017). The origin of mathematics and number sense in the cerebellum: with implications for finger counting and dyscalculia. Cerebellum \& Ataxias, 4(12), 1-16.

Violette, L. (1879). Dictionnaire Samoa-Français-Anglais et Français-Samoa-Anglais, précédé d'une grammaire de la langue Samoa. Paris: Maisonneuve et Cie, Libraires- Éditeurs.

Von Chamisso, A. (1837). Über die Hawaiische Sprache. Leipzig, Germany: Weidmannischen Buchhandlung.

Williams, F. E. (1936). Papuans of the Trans-Fly. Oxford: Clarendon Press.

Williams, H. (1893). Vocabulary of the language of Niue (Savage Island), part I. Journal of the Polynesian Society, 2(1), 17-24.

Williams, W. (1844). A dictionary of the New-Zealand language, and a concise grammar; to which are added a selection of colloquial sentences. Paihia, NZ: The Press of the Church Mission Society. 